\title{
Role of climate change in recovery of acidified surface waters
}

\author{
R. F. Wright ${ }^{1}$ and P. J. Dillon ${ }^{2}$ \\ ${ }^{1}$ Norwegian Institute for Water Research, Gaustadallèen 21, 0349 Oslo, Norway \\ ${ }^{2}$ Trent University, K9J 7B8 Peterborough, Ontario, Canada
}

\begin{abstract}
Surface waters in Europe and North America have begun to recover in response to decreases in emissions of acidifying pollutants to the atmosphere. Variations in climate influence chemical and biological recovery. Part of the EU project Eurolimpacs (Integrated project to evaluate the impacts of global change on European freshwater ecosystems) focuses on the interactive effects of acid deposition and climate on freshwater ecosystems. This special issue of Hydrology and Earth System Sciences is devoted to this topic, and consists of studies conducted in 8 countries on aspects regarding episodes, nitrate, dissolved organic carbon, recovery and biological effects.
\end{abstract}

\section{Introduction}

Acid deposition and acidification of surface waters has been a major environmental problem in many regions of Europe and eastern North America. International efforts to reduce the emissions of acidifying sulphur $(\mathrm{S})$ and nitrogen $(\mathrm{N})$ compounds have resulted in major reductions in acid deposition since the mid-1980s. In Europe much of this has been achieved through the United Nations Economic Commission for Europe's (UN-ECE) Convention on Long-range Transboundary Air Pollution (CLRTAP) (UNECE, 2002). In North America emission reductions have been regulated nationally through such legislation as the 1991 Canada - United States Air Quality Agreement and the US Clean Air Act.

As a result emissions of $\mathrm{S}$ and $\mathrm{N}$ in Europe have declined by about $65 \%$ and $25 \%$, respectively, in the period 1990 2004 (Tarrason et al., 2006). Acidified surface waters have begun to recover, with decreasing concentrations of sulphate $\left(\mathrm{SO}_{4}\right)$ and increasing acid neutralising capacity (ANC) and pH (Stoddard et al., 1999; Evans et al., 2001; Jeffries et al., 2003). Biological recovery has also been reported (Hesthagen et al., 2001; Holt and Yan, 2003).

Correspondence to: R. F. Wright

(richard.wright@niva.no)
Further chemical and biological recovery is expected in the future as emission of $\mathrm{S}$ and $\mathrm{N}$ continue to decline and surface waters respond to these reductions. Chemical recovery in response to future changes in emissions has been modelled for several acid-sensitive regions in Europe as part of the EU projects RECOVER:2010 and EMERGE (Wright et al., 2005).

It has long been apparent, however, that climatic variations affect acidification and recovery of surface waters. The effects can be episodic, such as acid pulses caused by seasalt events (high winds) (Hindar et al., 1995) or by droughtinduced changes in catchment redox processes (Dillon et al., 2003a, b), seasonal, such as the typical pattern of low concentrations of $\mathrm{NO}_{3}$ in summer and high concentrations in winter (Stoddard, 1994), and long-term, such as the increase in dissolved organic carbon concentrations in many surface waters during the 1990s (Evans et al., 2005).

\section{Structure of the special issue}

The articles are grouped by topic rather than by country in which the studies were carried out (Table 1). The first 5 articles deal with climate-induced short-term events (acid episodes) that affect the recovery process. Studies on episodes come from the UK (Evans et al., 2008), Norway (Wright, 2008), Sweden (Laudon, 2008), Italy (Rogora et al., 2008), and Canada (Aherne, 2008). The next 3 articles address variations in nitrate $\left(\mathrm{NO}_{3}\right)$ concentrations, two from Norway (de Wit et al., 2008; Hole et al., 2008) and one from Poland (Rzychoń and Worsztynowicz, 2008). These are followed by 2 articles dealing with dissolved organic carbon (DOC) concentrations, one in Sweden (Laudon and Buffam, 2008), and one in Finland (Futter et al., 2008). Three articles deal with recovery from acidification, two in Finland (Posch et al., 2008; Vuorenmaa and Forsius, 2008), and one in the Czech Republic (Hardekopf et al., 2008). Finally there are two articles dealing with biological aspects, both from Norway (Kroglund et al., 2008; Lydersen et al., 2008).

Published by Copernicus Publications on behalf of the European Geosciences Union. 
Table 1. Articles (denoted by first author) included in this special issue placed into a matrix of topics and countries.

\begin{tabular}{|c|c|c|c|c|c|c|c|c|}
\hline Topics & Norway & Sweden & Finland & $\begin{array}{l}\text { Countries } \\
\text { UK }\end{array}$ & Czech Republic & Poland & Italy & Canada \\
\hline Episodes & Wright & Laudon & & Evans & & & Rogora & Ahearn \\
\hline $\mathrm{NO}_{3}$ & $\begin{array}{l}\text { Hole } \\
\text { de Wit }\end{array}$ & & & & & Rzychoń & & \\
\hline DOC & & Laudon & Futter & & & & & \\
\hline Recovery & & & $\begin{array}{l}\text { Posch } \\
\text { Vuorenmaa }\end{array}$ & & Hardekopf & & & \\
\hline biology & $\begin{array}{l}\text { Kroglund } \\
\text { Lydersen }\end{array}$ & & & & & & & \\
\hline
\end{tabular}

The majority of these articles report work conducted as part of the EU project Eurolimpacs (Integrated project to evaluate the impacts of global change on European freshwater ecosystems) and associated national research. One of the work packages in Eurolimpacs deals specifically with the combined impact of acid deposition and climate change on freshwater ecosystems. The work reported here comes from the first phases of Eurolimpacs. Eurolimpacs will continue through January 2009.

Acknowledgements. This special issue was prepared with financial support of the Eurolimpacs project (the Commission of European Communities GOCE-CT-2003-505540), the Research Council of Norway, the Norwegian Institute for Water Research. We thank J. McCulloch for facilitating this special issue and help with the editing. We thank A. M. Smelhus Sjøeng at NIVA for able assistance in the editorial work.

Special Issue "Role of climate change in recovery of acidified surface waters (EUROLIMPACS)":

http://www.hydrol-earth-syst-sci.net/special_issue89.html.

\section{References}

Aherne, J.: The impacts of future climate change and sulphur emission reductions on acidification recovery at Plastic Lake, Ontario, Hydrol. Earth Syst. Sci., 12, this special issue, 2008.

de Wit, H. A., Hindar, A., and Hole, L.: Winter climate affects longterm trends in stream water nitrate in acid-sensitive catchments in southern Norway, Hydrol. Earth Syst. Sci., 12, this special issue, 2008.

Dillon, P. J., Skjelkvåle, B. L., Somers, K. M., and Tørseth, K.: Coherent response of sulphate concentrations in Norwegian lakes: relationships with sulphur deposition and climatic indices, Hydrol. Earth Syst. Sci., 7, 596-608, 2003a.

Dillon, P. J., Somers, K. M., Findeis, J., and Eimers, M. C.: Coherent response of lakes in Ontario, Canada to reductions in sulphur deposition: the effects of climate on sulphate concentrations, Hydrol. Earth Syst. Sci., 7, 583-595, 2003 b.

Evans, C., Reynolds, B., Hinton, C., Hughes, S., Norris, D., Grant, G., and Williams, B.: Effects of decreasing acid deposition and climate change on acid extremes in an upland stream, Hydrol. Earth Syst. Sci., 12, this special issue, 2008.

Evans, C. D., Cullen, J., Alewell, C., Kopácek, J., Marchetto, A., Moldan, F., Prechtel, A., Rogora, M., Veselý, J., and Wright, R. F.: Recovery from acidification in European surface waters, Hydrol. Earth Syst. Sci., 5, 283-298, 2001, http://www.hydrol-earth-syst-sci.net/5/283/2001/.

Evans, C. D., Monteith, D. T., and Cooper, D. M.: Long-term increases in surface water dissolved organic carbon: Observations, possible causes and environmental impacts, Environ. Pollut., 137, 55-71, 2005.

Futter, M., Starr, M., Forsius, M., and Holmberg, M.: Modelling the effects of climate on long-term patterns of dissolved organic carbon concentrations in the surface waters of a boreal catchment, Hydrol. Earth Syst. Sci., 12, this special issue, 2008.

Hardekopf, D., Horecky, J., and Kopacek, J.: Predicting long-term recovery of a strongly acidified stream using MAGIC and climate models (Litavka, Czech Republic), Hydrol. Earth Syst. Sci., 12, this special issue, 2008.

Hesthagen, T., Forseth, T., Saksgård, R., Berger, H. M., and Larsen, B. M.: Recovery of young Brown Trout in some acidified streams in Southwestern and Western Norway, Water Air Soil Poll., 130, 1355-1360, 2001.

Hindar, A., Henriksen, A., Kaste, Ø., and Tørseth, K.: Extreme acidification in small catchments in southwestern Norway associated with a sea salt episode, Water Air Soil Poll., 85, 547-552, 1995.

Hole, L., de Wit, H., and Aas, W.: Influence of summer and winter climate variability on nitrogen wet deposition in Norway, Hydrol. Earth Syst. Sci., 12, this special issue, 2008.

Holt, C. and Yan, N. D.: Recovery of crustacean zooplankton communities from acidification in Killarney Park, Ontario, 19712000: pH 6 as a recovery goal, Ambio, 32, 203-207, 2003.

Jeffries, D. S., Clair, T. A., Couture, S., Dillon, P. J., Dupont, J., Keller, W., McNicol, D. K., Turner, M. A., and Weeber, R.: Assessing the Recovery of Lakes in Southeastern Canada from the Effects of Acid Deposition, Ambio, 32, 176-182, 2003.

Kroglund, F., Rosseland, B. O., Teigen, H. C., Salbu, B., Kristensen, T., and Finstad, B.: Water quality limits for Atlantic salmon (Salmo salar L.) exposed to short term reductions in $\mathrm{pH}$ and increased aluminum simulating episodes, Hydrol. Earth Syst. Sci., 12, this special issue, 2008.

Laudon, H.: Recovery from episodic acidification delayed by 
drought and high sea salt deposition, Hydrol. Earth Syst. Sci., 12, this special issue, 2008.

Laudon, H. and Buffam, I.: Impact of changing DOC concentrations on the potential distribution of acid sensitive biota in a boreal stream network, Hydrol. Earth Syst. Sci., 12, this special issue, 2008.

Lydersen, E., Aanes, K. J., Andersen, S., Andersen, T., Brettum, P., Bækken, T., Lien, L., Lindstrøm, E. A., Løvik, J. E., Mjelde, M., Oredalen, T. J., Solheim, A. L., Romstad, R., and Wright, R. F.: Ecosystem effects of thermal manipulation of a whole lake, Lake Breisjøen, southern Norway (THERMOS project), Hydrol. Earth Syst. Sci., 12, this special issue, 2008.

Posch, M., Aherne, J., Forsius, M., Fronzek, S., and Veijalainen, N.: Modelling the impacts of European emission and climate change scenarios on acid-sensitive catchments in Finland, Hydrol. Earth Syst. Sci., 12, this special issue, 2008.

Rogora, M., Arese, C., Balestrini, R., and Marchetto, A.: Climate control on sulphate and nitrate concentrations in alpine streams of Northern Italy along a nitrogen saturation gradient, Hydrol. Earth Syst. Sci., 12, this special issue, 2008.

Rzychon, D. and Worsztynowicz, A.: What affects the nitrogen retention in Tatra Mountains lakes' catchments in Poland?, Hydrol. Earth Syst. Sci., 12, this special issue, 2008.

Stoddard, J. L.: Long-Term Changes in Watershed Retention of Nitrogen: its causes and aquatic consequences, 223-284, in: Environmental Chemistry of Lakes and Reservoirs, edited by: Baker, L. A., American Chemical Society, Washington, D.C., 1994.
Stoddard, J. L., Jeffries, D. S., Lükewille, A., Clair, T. A., Dillon, P. J., Driscoll, C. T., Forsius, M., Johannessen, M., Kahl, J. S., Kellogg, J. H., Kemp, A., Mannio, J., Monteith, D., Murdoch, P. S., Patrick, S., Rebsdorf, A., Skjelkvåle, B. L., Stainton, M. P., Traaen, T. S., van Dam, H., Webster, K. E., Wieting, J., and Wilander, A.: Regional trends in aquatic recovery from acidification in North America and Europe 1980-95, Nature, 401, 575-578, 1999.

Tarrason, L., Fagerli, H., Klein, H., Simpson, D., Benedictow, A. C., Vestregn, V., Rigler, E., Emberson, L., Posch, M., and Spranger, T.: Transboundary Acidification, Eutrophication and Ground Level Ozone in Europe from 1990 to 2004 in support for the review of the Gothenburg Protocol, EMEP Status Report 1/2006, Meteorological Institute, Oslo, 2006.

UNECE: available at: http://www.unece.org/env/lrtap/, last access: 27 February 2008, 2002.

Vuorenmaa, J. and Forsius, M.: Recovery of acidified Finnish lakes: trends, patterns and dependence of catchment characteristics, Hydrol. Earth Syst. Sci., 12, this special issue, 2008.

Wright, R. F.: The decreasing importance of acidification episodes with recovery from acidification: an analysis of the 30-year record from Birkenes, Norway, Hydrol. Earth Syst. Sci., 12, this special issue, 2008.

Wright, R. F., Larssen, T., Camarero, L., Cosby, B. J., Ferrier, R. C., Helliwell, R. C., Forsius, M., Jenkins, A., Kopácek, J., Majer, V., Moldan, F., Posch, M., Rogora, M., and Schöpp, W.: Recovery of acidified European surface waters, Environ. Sci. Technol., 39, 64A-72A, 2005. 